Analysing Crisis Parliamentary Discourse in Greece: Who Should We Blame?

Journal of Common Market Studies, 2019

Authors:

Corresponding Author:

Dr Stella Ladi

Senior Lecturer in Public Management, School of Business \& Management, Queen Mary University of London, UK.

Address: Mile End Road, Bancroft Building, Room 3.44g, London E1 4 NS UK.

Tel.: +44 (0) 2078826987

Email: s.ladi@qmul.ac.uk

and Associate Professor, Department of Political Science and History, Panteion University, Athens, Greece.

Address: 136 Andreas Syggrou Avenue, Athens 176 71, Greece

and

Dr. Vasiliki Tsagkroni

Lecturer of Politics, Department of Political Science, Leiden University

v.tsagkroni@fsw.leidenuniv.nl, +31715272727

5A.01, Pieter de la Court Building, Wassenaarseweg 52, 2333 AK Leiden 


\section{Analysing Crisis Parliamentary Discourse in Greece: Who Should We Blame?}

\section{Abstract}

This article analyses differences in the variety of political rhetoric on structuring and legitimizing argumentation and strategies during periods of economic and political crisis. Driven by developments in theory about blame-shifting and 'exogenisation' of the causes of crisis as well as employing advanced techniques of analysis, it focuses on the parliamentary bailout debates in Greece during the 'crisis' period (2009-2015). By means of Computer Assisted Content Analysis (CATA) it analyses the content of arguments which relate to blame shift. It is shown that blame-shifting is much more complex that just blaming the external enemy and often takes the form of 'historical blame shifting', turning the blame to previous governments. It is revealed that party leaders often use a much more polemic discourse than Members of Parliament (MPs). Finally, it is shown that blame-shifting diminishes once a party comes to power following Mair's (2009) representative versus responsible government argument.

\section{Introduction}

Political discourse in the last decade has increasingly been characterised by exaggerated claims, blame shift, a lack of attention and in some cases the promotion of fake news in order to achieve political aims (Bennett, 2016, Allcott and Gentzkow, 2017). The media talk about the rise of populism and academics are debating the exact meaning, content and causes of populism (Mudde, 2007; Pappas, 2016). This controversial shift in political discourse can be observed across the political spectrum in what sometimes appears to be an unconscious race to the bottom. Party leaders, parliamentarians and party members are all inclined to use such discourse. 
In this article, we aim to measure blame-shifting and 'exogenisation' of the causes of the political and economic crisis (2009-2015) in Greece in order to evaluate how widespread this trend is in a crisis situation. We draw on the literature on blame shift during crisis and apply it to the impact of the Eurozone crisis upon parliamentary discourse in Greece along with the argument that blame shift increases during crises (Boin, Hart and McConnell, 2009). Greece is chosen since it was the country most dramatically hit by the financial crisis both economically and politically. Three Economic Adjustment Programmes (or Memoranda, in everyday language) have been negotiated and implemented in order to rescue the country from bankruptcy ${ }^{1}$. The austerity stemming out of these Programmes has economically, politically and socially shaken the country and the political status quo.

By means of Computer Assisted Content Analysis (CATA) the article analyses the content of arguments which relate to blame shift presented in parliamentary debates. From the analysis of these parliamentary debates we suggest that within the crisis period, from the first bailout in 2010 to the third in 2015, an increase in both blame shift and 'exogenisation' of the causes of crisis can be observed across the political spectrum. This 'exogenisation' is complex since it involves a domestic mediator between the 'external enemy' and the crisis which is portrayed as the 'old establishment'. This is what we call 'historical blame-shifting'. This type of 'exogenisation' has direct implications for the political system, for accountability mechanisms and thus for the implementation of policy reforms. Interestingly, when political parties become members of governing coalitions this type of blame shift seems to decline in comparison to their status as part of the parliamentary opposition. Evasion from the problem to other issues or technicalities is a common strategy. Finally, it is revealed that party leaders use a much more polemic discourse than MPs.

The article is organised into four sections. The first section critically discusses the literature on blame shift during crisis and elaborates on the research's argument. The second section

\footnotetext{
${ }^{1}$ The terms Economic Adjustment Programme, Memorandum and bailout agreement are used interchangeably throughout the article.
} 
provides the background to the Greek case study. The third section introduces the research questions and methodology used in the article. The final section analyses the findings of the research and provides some insights about the relationship between crisis and the 'exogenisation' of blame shift.

\section{Crisis, 'exogenisation' of blame and political discourse}

During the last decade 'crisis' and 'crisis management' have been at the centre of most discussions related to the European Union (EU) member states under financial assistance programmes. Nonetheless the academic literature is very limited. Boin, Hart and McConnell (2009) in their article on crisis exploitation argue that once it has been accepted that a crisis has erupted, the centre of attention turns to the causes of the crisis which often involves blame shifting and a significant degree of 'exogenisation'. The main characteristic of 'exogenisation' is an attempt to shift accountability for the crisis from the government to outside factors. Such factors can include natural events (e.g. tsunami or forest fires) or the unexpected actions of 'outgroups' (e.g. Islamic radicals, 'anarchists', greedy corporate managers etc). This does not mean that blame shift is not common practice beyond crisis, when governments are trying to avoid accountability for corruption scandals or day-to-day public administration failures. What is argued here is that this phenomenon and its political and policy implications are exacerbated during crises because it allows for more complex 'exogenisation' processes which will be discussed further. Crisis is defined as "events or developments widely perceived by members of relevant communities to constitute urgent threats to core community values and structures" (Boin, Hart and McConnell, 2009, p. 83).

The discussion of blame attribution which is very much related to blame shifting is not new. Powell and Whitten (1993) in their seminal article correlate the clarity of the responsibility for economic failures such as high unemployment, lack of growth etc. with voting behaviors and conclude that economic voting strongly interacts with political responsibility attribution. Since the eruption of the Eurozone crisis the discussion of blame attribution and voting 
behavior has re-gained ground. Karyotis and Ruedig (2015) explore the way blame attribution relates to the weakening of the Panellinio Sosialistiko Kenema (Panhellenic Socialist Movement, (PASOK) which was in power when the First Economic Adjustment Programme for Greece (2010) was signed. Their research is based on opinion poll analysis. Although they expected that blaming external actors such as the EU would affect voting choices, they find that this is not the case. Blaming the large parties (PASOK and Nea Democratia (New Democracy, ND) that have traditionally held power seems to constitute an important dimension of blame attribution. We will return to that later. Further relevant literature that has been developed is that of blame attribution by the media during the crisis (Capelos and Exadaktylos, 2015; Roose et al., 2017; Von Scheve, Zink and Ismer, 2016). Although the focus of this research is more sociological and is interested in the emotions of blame attribution, it also shows that in the case of Greece blame attribution in the media has been directed more towards the domestic political system than towards external actors. In this article we turn our attention away from the general public and the media to an actor which has been understudied although it plays a central role in blame shift: the political parties' elites via the analysis of their parliamentary discourse during the crisis.

The crisis in Greece and its effects upon the political discourse has been a topic of analysis since early 2009. Papadimitriou and Zarlatoulids (2015), for instance, examined the discourse of European policy makers on the initial stages of the crisis, highlighting such themes as corruption and chronic mismanagement that resulted in elevated levels of mistrust between Greek governments and the EU. Closer to the approach of this research, Vasilopoulou et al. (2014), conducting content analysis of parliamentary speeches, argued that the two mainstream parties of PASOK and ND engaged in mutual criticism and blame shifting for the crisis and the failure to initiate successful reforms over the years. Empirically, it is important to continue this work further in time. Additionally, Hatzidaki and Goutsos (2017) combine research on the Greek crisis discourse with various methodological perspectives for a better understanding of the Greek crisis as a socioeconomic episode and as a discourse construct. 
This research provides a new perspective on blame attribution by moving forward from focusing on existing theories of scapegoating and electoral strategies before the crisis to elaborating the theory of 'exogenisation' of blame during the crisis and its implication for the political system and policy reform processes of crisis-ridden countries.

More specifically, blame shifting is important not only because it affects voting behaviors but also because it determines policy change. Although crises and critical junctures are often seen as instances when policy change is more likely to occur, this has not always been the case in the EU member-states under financial assistance programmes during the Eurozone crisis (Ladi, 2014). This could be because often the aim is not to find viable solutions but to shift the blame. It has been suggested that the increase in populist discourse and blame-shifting during crisis may undermine agenda-setting and the implementation of policy or reforms (Ladi, 2016). Problems during the crisis have often been defined not with a focus on the introduction of reforms but rather by aiming to find somebody to blame for the problem and thus for the crisis. This was the case with the problem of youth unemployment in Greece during the crisis years. Although the issue was not new, it was framed by emphasizing that it was exacerbated due to austerity. This meant that the blame was shifted to the troika (European Commission, EC; European Central Bank, ECB; International Monetary Fund, IMF). Long-standing endogenous parameters of the problem such as the lack of a growth strategy or the selfserving higher education system were hushed up. The 'exogenisation' of the crisis by policy makers meant that long-standing endogenous causes of the problem were overlooked. Instead, a populist discourse put emphasis on emotions and on shifting the blame to an exogenous 'enemy'. Such a discourse closed opportunities for meaningful agenda-setting and viable solutions, undermined the ownership of the austerity measures and may have led to false promises.

The 'exogenisation' of the crisis serves politicians and policy-makers whose primary aim is to avoid blame. As Weaver (1986) suggested, politicians are very often motivated by their desire 
to avoid blame for unpopular action or policy mistakes rather than to claim credit for popular actions. Frames that 'exogenise' accountability often refer to forces of nature, 'outgroups' or uncontrollable events such as economic recession. What is revealed by the Greek crisis, which adds to the complexity but may explain a lot, is that 'exogenisation' may take even more complicated forms than blaming an 'external enemy' such as the EU. In the case of Greece during the Eurozone crisis the 'exogenisation' concerned the 'external enemy' as well as what was portrayed as the 'old establishment' which was presented as colluding with the 'external enemy'. In such cases, as Mair (2009) argues, to mobilize against the government equals mobilizing against the EU since a lot of the policies now derive from the EU level - and this is pointed out by 'protest' parties, especially during crises. It is common for 'protest' parties that have gained momentum because of the crisis to emphasise such' exogenisation' and blame centre parties which were traditionally the parties of government - what is called the 'old establishment' (Morlino and Raniolo, 2017). For this leap to be successful the 'old establishment' needs to be directly connected with the 'external enemy'. If this is the case, the 'exogenisation' of the crisis in the EU member states under financial assistance programmes would be portrayed by a shift of blame for both the crisis and the proposed solutions to the EU and the troika. This argument is further explored by analysing data on parliamentary discourse.

Interestingly, when these political forces become members of governing coalitions the 'exogenisation' of the crisis appears to decline. This can be seen as evidence of the old dilemma of representative versus responsible government (Mair, 2009). 'Protest' parties during crisis act as representatives - amongst others - by articulating interests that are losing their ground due to sudden changes as well as to citizens' disappointment and anger. They often express all these in radical terms by 'exogenising' the crisis and the solutions agreed in the way described above and proposing new, fundamentally different political programs. When they come to government they have to deliver on their promises, and this becomes almost impossible since they have to act in a responsible way and deliver in areas that are not 
about politics but about policy, continuity and prior international agreements (Mair, 2009; Morlino and Raniolo, 2017). Compromise is often inevitable, since the implementation of a fundamentally different political program would normally signify very high costs. The case of Synaspismos Rizospastikis Aristeras (Coalition of the Radical Left, SYRIZA) and the U-turn in their political decisions and policies implemented after the 2015 referendum shows how their role and discourse while in opposition could not be the same when in government. In order to act responsibly and avoid the possibility of Grexit, they had to make bargains with some of their representativeness' (Morlino and Raniolo, 2017).

\section{Background to the Greek case study}

The financial crisis of 2008 was based on the combination of debt and leverage of financial proliferation and securitisation, resulting in imbalances in trade, investment and consumption (Morgan, 2009). The Eurozone crisis which started in 2009 as a result of the 2008 global financial crisis, and more specifically its impact upon Greece, is a telling case-study for exploring blame shifting in parliamentary discourse during crisis. In this section, a brief consideration of the changing situation in Greece is presented in order to contextualise this blame shifting. What is observed is an attempt to 'exogenise' accountability for the crisis and to frame it as the result of the international economic recession and/or the failure of the Eurozone. It is important to note that the first step for this 'exogenisation' is the exposure of the 'internal allies' of these exogenous factors. These 'internal allies' are elements of the 'old' political establishment which is blamed for its choices and for surrendering to the pressures of the European partners. The crisis is thus defined as mainly international and/or European but it is often claimed that it has been exacerbated because of the actions of the 'old' establishment ${ }^{2}$.

\footnotetext{
2During the period of the three Programmes (2009-2015), the Greek political scene can be separated into three major competing groups. Speaking in terms of the left-right scale of the political scene in Greece, PASOK, ND, and POTAMI represent the centre, Laikos Orthodoxos Synagermos (Popular Orthodox Rally, LAOS) the neo-Nazi Golden Dawn and Anexartitoi Ellines (Independent Greeks, ANEL) the right, and Kommounistiko Komma Elladas (Communist Party of Greece, KKE) and SYRIZA the left.
} 
The Greek economy was in a recessionary phase in 2008 , with continuous declines in inflation and rising unemployment levels. Nevertheless, the causes of the Greek financial crisis arise from chronic aggravating problems and policy decisions that have been implemented along with the financial and economic global crisis. The increase in public debt in combination with the country's recession since 2008, resulted in the Greek economy being particularly vulnerable to the effects of the 2008 global crisis, and this ultimately required the use of a support mechanism in order to avoid its permanent cessation. As a result of this situation, Prime Minister George Papandreou publicly announced in 2009 that the Greek public deficit figures had been understated, resulting in the start of an austerity trail in 2010. A key axis of the strategy was to tie up fiscal adjustment and restart the real economy so that the country might escape the vicious cycle of deficits and recession. However, the results weren't the ones anticipated, and the capacity of the country to borrow from the financial markets weakened, placing Greece at the epicentre of the Eurozone debt crisis (Dinas and Rori, 2013).

Since 2010 there have been three Economic Adjustment Programs (2010, 2012 and 2015) and a total loan of 326 billion Euros has been negotiated with the troika, to which the European Stability Mechanism (ESM) was added in 2015. The negotiations and the terms agreed comprised harsh austerity measures including deep budget cuts, tax increases, privatizations, a wide range of structural reforms, and a demand for curbing tax evasion. In the meantime, by 2014 Greek GDP had fallen by almost $26 \%$ and unemployment had risen to almost $27 \%$ (Eurostat, 2015), with youth unemployment reaching 50\% in the first months of 2016. In 2014 the Greek government managed to access the markets for the first time after some of the structural reforms had been concluded and a modest surplus had been achieved. Nevertheless, by 2015 the public debt to GDP ratio was 177,4\% (Eurostat, 2016). Voices inside and outside the country were pointing to both the unsustainability of the Greek debt and the ineffectiveness of the austerity measures, and serious disagreement between the IMF and the European partners continues to this day (i.e. Ekathimerini, 7/2/17). 
Despite these mildly positive figures, reform fatigue and a domestic political deadlock led to the snap parliamentary elections of January 2015 which led to the fall of the Samaras government. A SYRIZA-led coalition government came into power. The political system of Greece has effectively been in turmoil since 2010 and this is why it is necessary to conduct an analysis of the changing parliamentary discourse. The political changes since 2010 can be described as the end of the 'old' political system and the emergence of new parties, coalitions and dynamics. There are the three main changes that can be observed. First, the two centrist parties that dominated Greece's political scene since the transition to democracy in 1974 have lost ground. PASOK, the socialist party which was in power when the crisis initially erupted, fell from approximately $44 \%$ of the vote in 2009 to $4.7 \%$ in the January 2015 elections. The conservative ND lost approximately $9.5 \%$ of the vote from the 2012 elections, collecting $36.34 \%$, while the fascist Golden Dawn was strengthened, acquiring $6.9 \%$ of the vote, gaining 17 parliamentary seats (Hellenic Ministry of Interior, 2015) and becoming the third largest party in parliament. The big winner in the crisis was the radical left SYRIZA, which rose from 4.6\% of the vote in 2009 to $36.3 \%$ in January 2015 and thus won. As Rori (2016) points out, since the 2012 elections an economic approach to voting attitude seems to explain the flow of voters towards SYRIZA in 2015, partly as a protest vote against the economic decisions of the previous coalition government that led to the second bailout (Konstantinidis, 2015).

Second, coalition governments have replaced strong one-party governments which used to be the norm in Greek politics. Since 2015 the country is governed by a paradoxical coalition between the 'radical' left-wing party, SYRIZA, a party whose programme is still based on the Marxist theory of class struggle (Pappas and Aslanidis 2015), and the radical right-wing party ANEL that emerged as a spin-off from ND. A typical case of a populist radical right-wing party, following Mudde's (2007) definitions, ANEL constructs a narrative of the people in ethnic terms and combines traditional themes of the conservative right-wing agenda such as antiimmigration, religion and the role of the family. The previous governing coalition formed after the 2012 elections comprised the socialist PASOK, the conservative ND and the pro-European 
left-wing Demokratiki Aristera (Democratic Left, DIMAR), although the latter subsequently disagreed with some of the measures and left the coalition. Coalition governments in Greece are seen as more fragile than one-party governments and they invariably do not last full fouryear terms.

Third, internal political debate in Greece was reduced to a memorandum/ anti-memorandum cleavage that after the Tsipras government's shift to adopting the third Economic Adjustment Programme was succeeded by a Euro versus 'return to a national currency' cleavage. The crisis in Greece was increasingly framed as a 'war' with the European partners and especially the Germans who were perceived as the 'enemy' or the 'occupying force' (in the most extreme versions of this discourse) (Dinas and Rori, 2013; Lowen 2015). The agreement on a third bailout package, which halted a race towards default and potentially a Grexit, was presented as a 'coup' against the government (ekathimerini.com, 15/7/2015). This provocative discourse of the government and often of the opposition has repeatedly been described as populist and is the focus of our analysis in this article. Pappas (2014) has described Greece as a populist democracy exemplified by three characteristics: first, a single dominant division between the good 'people' and the evil 'establishment'; second, conflict and polarization rather than consensus and moderation as the preferred political mode; and third, the centrality of personal authority which counts more than the impersonal institutions and the rule of law. A content analysis of the first years of the crisis argues for a populist discourse by all parties in Parliament, with an emphasis on blame-shifting (Vasilopoulou et. al. 2014). We aim to move this research forward and further analyse the blame-shifting, assess and explain its variations across parties and time.

\section{Research questions and methodology}

Two main questions are put forward based on what has been outlined above and are further explored by means of analysis of the parliamentary discourse during the vote on the three Economic Adjustment Programmes. First, can 'exogenisation' of the crisis and blame-shifting 
be much more complex than just blaming exogenous factors? During the Greek crisis the 'old establishment' which was the 'internal ally' of the EU was the first entity to be blamed and as a consequence the EU, the IMF, the West and globalization more generally were also blamed. And second, does this 'exogenisation' and blame-shifting discourse softens when opposition and protest parties enter government and therefore are pushed to act responsibly? In the case of Greece there is such evidence both during the conservative Samaras government (2012), which held an anti-memorandum position before his election but then implemented the reforms, and during the radical left SYRIZA government (2015) which eventually acted in a very similar way to all previous governments.

Where 'exogenisation' reflects the shifting of blame for the crisis from the government to exogenous factors we expect that:

H1: 'Exogenisation' discourse of both the causes of the problem and the responsibility (blame shifting) over solutions, is prominent during the crisis. Discourse levels differ between the political 'eras' signified by the three Economic Adjustment Programmes and between party leaders and MPs.

$\mathrm{H} 2$ : 'Exogenisation' discourse levels are higher for parties in opposition than for the governing party. A prominent mechanism of blame shifting when in government is to evade focusing on the real problem.

With regard to the operationalisation of the key concept 'exogenisation', we focus on the analysis of texts. Texts have been a major tool used to examine the identity of political parties. They are utilised in our research to examine the level and type of 'exogenisation' in parliamentary debate on the three Economic Adjustment Programmes signed between Greece and its creditors in return for loans. For the purposes of this research, 'exogenisation' is about what and who is to be blamed for the ongoing crisis. Looking at the original texts of the parliamentary debates, there are two main actors, the established political scene and the EU. It is important to compare the blame-shifting over time along with the parties that stand 
in favour or against the memoranda, to identify possible patterns and differences within their discourse with regard to their role when in government. Additionally, it is equally important to measure the populist argument of 'us' versus 'them' in order to highlight the level of identification with the people, who have been forced to face the ongoing crisis by those responsible for causing it.

Our research uses content analysis in order to isolate and measure 'exogenisation' focusing on the discourse of party MPs and party leaders. Although we would expect the analysis of such discourse to have similar results for both MPs and leaders, it is interesting to examine intra-party variations, especially differences in the 'exogenisation' intonation of the discourse of party leaders and party MPs. In all three Economic Adjustment Programmes many members of the governing parties were not supportive of the proposed measures. This was especially the case in 2015 and the coalition government of SYRIZA-ANEL, which followed an antimemorandum discourse throughout its electoral campaign. Having said that, it is worth noting that of all parties which voted on the bailouts, SYRIZA has had the least losses in parliamentary votes. Even after it split in the summer of 2015 , it remained the only party which maintained such a high level of discipline when voting for austerity measures. ND and PASOK lost a lot more MPs whilst voting for the bailouts (Rori, 2016). Given the levels of dissent and challenges that leaders had to face during the parliamentary votes with respect to party discipline, the distinction between party leader and MPs seems rather essential to address our research question.

Despite the existing literature on party leaders' speeches, there is a relative lack of research focusing specifically on parliamentary speeches by party leaders. In a party conference context, for instance, Finlayson and Marring (2008) explored the contribution of political speeches to understanding political institutions, ideologies and strategies, by analysing the rhetoric of Tony Blair's last speech as PM, while Pettit (2012) focuses on identifying civic republicanism in Spain by analysing José Luis Rodríguez Zapatero's speeches as an PM. There are also some parallel studies on televised leadership debates using content analysis (Bastien 
2018; Allen, Bara and Bartle 2010). In this article, what we do is separate the party leader and the party MPs in a parliamentary context, in order to make comparisons on their stance in the parliament and explore how this dilemma of representative versus responsible government is articulated in parliamentary discourse in this separate role of actors.

We examine the parliamentary debates using qualitative content analysis. The first stage of the analysis focuses on a manual examination of the text itself, in terms of providing a systematic and objective study of both the characteristics and context of the 'message'. A comparison of the changes regarding the level of 'exogenisation' over time is undertaken in order to compare the changes in party parliamentary discourse over parties and time. In its second stage, the project uses HAMLET II software to conduct qualitative computer assisted textual analysis (CATA). As Bara, Weale and Bicquelet (2007) stress in their work on the analysis of parliamentary debates with computer assistance, a 'semi-automated' CATA is an efficient approach for examining and measuring assumptions about policies and political behaviour $(2007$, p. 580). The measurement of the research, therefore, relies on this dictionary tactic in which the share of words that are considered to be indicators are counted (Rooduijn and Pauwels, 2011).

Therefore, such coding has been done by assigning the text to pre-established categories which are formed on the basis of four specific topics (seven categories): the people (referring to the populist argument 'we' as the 'people' we represent), attitudes towards the established political scene (pro-consensual, anti-establishment), attitudes towards the EU and international factors (pro-EU/International, anti-EU/international) and attitudes towards the memorandum (pro-memorandum, anti-memorandum) (see Appendix 2). The units of analysis for this project are the parliamentary debates, whereas the units of measurement contain words and phrases identified in the text and reflect the established categories, following the example of recent works that have dealt with the concept and the ability to measure populism (quantitative: Panizza 2005, qualitative: Taggart 1996, Mudde 2007, computer-based: Armory and Armory 2005, human-coded content analysis: Jagers and Walgrave 2007, Hawkins 2009). 


\section{Discussion and Findings}

Reflecting back to the work of Boin, Hart and McConnell (2009), the results of our analysis highlight a pattern of blame-shifting on the ongoing economic and political crisis, in which the blame shifts from internal factors (e.g. established political scene and the government) to exogenous factors (e.g. EU) (H1). And while we rarely see the government taking responsibility for its previous actions, with the exception of Papandreou in 2010, in most of the cases the 'exogenisation' points clearly to the 'old' establishment, the major parties that created the dipole in the country's political scene: ND and PASOK $(\mathrm{H} 1)$. The stronger results arising from the analysis of the data reflect the shift in the behaviour of opposition parties, and mainly of SYRIZA before and after it formed a government in 2015 (H2).

Our findings validate our $\mathrm{H} 1$. Although this research does not compare levels with non-crisis periods, the data points to prominent 'exogenisation' discourse of both causes and responsibility (blame shifting) over solutions during the crisis. This suggests a higher level of blame-shifting and direct references to the people from the opposition parties rather than the governing party which introduces and supports the Economic Adjustment Programme to the Parliament.

Looking at the cases individually, in terms of party leaders and party MPs across all three parliamentary debates, a few conclusions can be drawn. Our results point to an overall maximum score of negative references to 'the establishment'. More specifically, the content of the 2010 debate indicates a 'historical blame-shifting' attribution context for the crisis against the established political scene and governments, dating back to the regime change after 1974. This is the case at a leadership level, from both parties in opposition (SYRIZA and LAOS) but also from the governing party (PASOK), with the latter focusing more specifically on deflecting the blame from previous PASOK governments to those of the conservative party of ND between 2004 and 2009.

This 'historical blame-shifting' highlights the responsibility for policy errors by previous governments and the inability of the status quo parties (mainly PASOK and ND) to govern, as 
they are the ones responsible for leading the country into the crisis. Papandreou's discourse in 2010 is characterised by the common PASOK attitude at the time, trying not to 'exogenise' but also to 'endogenise' the blame that led the country to the first memorandum, in an effort to underline the responsibility of political actors but also of individual citizens in an attempt to unify the country.

Having said that, attention on 'exogenisation' does not only focus on internal factors. From both right (LAOS and Golden Dawn) and left (SYRIZA and KKE), the responsibility for the crisis is placed on the EU and international factors (see Figure 1 and Appendix 3, Figures 2, 3 and $4)^{3}$. It is the EU and its assertive policies since Greece's accession to the EU that created the circumstances and the fertile ground for the crisis, according to this discourse. These external factors were obvious scapegoats and the targets of negative discourse even prior the crisis, especially from the actors of the extreme parties (Golden Dawn and KKE). Bringing the EU and IMF into the debate also points to a global dimension of the crisis, redirecting the blame to something greater and therefore beyond national control and accountability. What is also interesting is the populist appeal to 'the people', or in other words the identification of those that stand against the established system and the foreign influences - not only by party leaders but also by MPs from all parties represented in the parliament in all three bailout debates (see Figure 1 and Appendix 3, Figure 5). By emphasising this discourse, the parties make a clear distinction between 'them' (the actors responsible for the crisis) and 'us', a direct reference to the 'people', the electorate, the only blameless ones against whom these injustices have been taking place.

In relation to the 'exogenisation' a further aspect that needs to be examined is the positivecontent towards both internal and external factors, along with comments on the proposed policies as part of the loan deal. As expected, most of the positive references come

\footnotetext{
${ }^{3}$ Figures 1, 2 and 3 are horizontal bar graphs, distributing bars along the $y$-axis. Elements in the same row of a matrix are grouped together, in this case the categories. Each bar represents one category, and the total salience of each category in each case of parliamentary discourse. Therefore, the length of each shade in the bar represents the salience \% of each actor (party MPs or leader).
} 
from the parties in government, arguing in favour of the memorandum, both on a party and party leader level (ANEL in 2015, Papandreou in 2012 and Tsipras in 2015) (see Figure 1 and Appendix 3, Figure 4). Similarly, we see positive comments towards the established political scene and parliament by governing parties, when seeking collaboration and support on the upcoming parliamentary vote of the austerity measures (Samaras in 2012, ANEL in 2015 and Papandreou in 2010). Interestingly, there is also a small but rather noticeable trend among several opposition parties in favour of mutual collaboration for a solution to the crisis, going beyond the variable of blame-shifting towards a concerted effort to end the crisis. Furthermore, there is a limitation to directly addressing the negative aspect of the proposed austerity measures, with the anti-memorandum discourse coming once more from the right (Golden Dawn in 2015 and LAOS in 2012) and left (KKE in 2010 and 2015 and Tsipras from SYRIZA in 2015) (see Figure 1 and Appendix 3, Figures 2, 3, and 4). And while one would expect this attitude from the communist and neo-fascist parties, since they have been keeping a consistent negative attitude from the outset, the stance of the governing and coalition governing parties is rather interesting. In these cases the leadership and party MPs stress the necessity of the austerity measures while at the same time distancing themselves from the responsibility their parties bear. In other words, governing parties acknowledge the importance of the austerity measures and therefore they present an argumentation on the choice to bring these measures to the parliament for approval, at the same time eschewing the ownership of the austerity measures by not focusing on their role in the process. This could be interpreted as an attempt to minimise electoral losses but also to acknowledge the negative effects of austerity.

As regards the initial assumption that the leader is in line with the party, the findings point to a significant difference across the three Economic Adjustment Programmes debates. The populist appeal is registered higher at a leader level in comparison to party MPs (Papandreou and Tsipras in 2010, Genimmata in 2015), as well as putting the blame on the 'old establishment' (again by Papandreou and Tsipras in 2010). Papandreou at the time appears 
to make an appeal to the people by highlighting the importance of the bailout programme as a requirement for the country to survive the economic crisis. At the same time (as stated above) this does not deny the responsibility of his party for its contribution to the crisis throughout its previous time in government. In the case of the 2015 debate, for SYRIZA the difference is on the 'anti-memorandum' discourse, where Tsipras, despite being the prime minister presenting the bailout programme, registers high scores, a high rate of $+1.97 \%$ in comparison to his party's score. Finally, ANEL is also a case where party leader and party follow a rather different discourse. Significantly, at a party level we see rather high scores on 'promemorandum' and 'pro-consensus' in comparison to their party leader Kammenos, with $2.24 \%$ and $-2.5 \%$ respectively (see Figure 1 and Appendix 3, Figure 5). What appears to be the case here is that the party leader scores higher in rates of populism whereas the party shares a higher rate of responsibility. This disparity at intra-party level, especially in the case of SYRIZA and ANEL in 2015, highlights a trend of differentiation between leader and MPs as regards the proposed bailout plan. Kammenos responds to the popular appeal of the electorate, where MPs pledge to their responsibility to provide explanations and argue in favour of the bailout plan to explain their supporting vote (see Appendix 1).

We now examine further our H2, that 'exogenisation' discourse levels are higher for parties in opposition than for the governing party. This necessitated a manual examination of the original documents and their context so as to identify potential external factors that influence their focus. The initial analysis points to a rather similar discourse in 2010 and 2012, although this changes in 2015: it is the year when three new parties enter the debate -Golden Dawn, ANEL and POTAMI - while there is a change in the leadership of PASOK, KKE and ND. And while the focus of 'exogenisation' appears to remain the same for KKE and PASOK, both at party and leader level, there is a change in the cases of SYRIZA and ND, especially concerning the MPs at the party level.

Golden Down and POTAMI in 2015 have the highest score of targeting the established political scene with $5.41 \%$ and $5.1 \%$, respectively. Since both have entered the debate for the first 
time, this may reflect their alternative rhetoric against the established elite that led the country to this ongoing crisis. Golden Dawn, for instance, seems to emphasise this specific aspect by invoking with strong words the 'cynical' attitude of the previous government and referring to it as a 'deception' that led to 'bloodstained' measures and the 'destruction' of the country, a modern national 'tragedy' (Golden Dawn, 2015). POTAMI on the other hand focuses mainly on the governance and anti-memorandum discourse of SYRIZA before and after the election of 2015, highlighting the irony of SYRIZA, perceived for the first time as 'establishment', being the one to introduce a new Memorandum to the parliament. The party invokes the SYRIZA government's 'lies' and 'divisive' rhetoric along with the 'propaganda of heroism' that isolates the country within the European family (POTAMI, 2015). Golden Dawn accuses the previous regimes whereas POTAMI focuses on the emerging radical actors of the crisis. Additionally, this difference between the two parties can be explained by the difference stance in the pro (POTAMI) /anti (Golden Dawn) memorandum cleavage that affects their blame attribution. An additional factor is that POTAMI has been seeking to form a coalition with SYRIZA since its inception, even before the elections of 2015. Remaining outside the coalition enables the party to take advantage of its role as opposition and exogenise the blame attribution towards the government.

With regard to $\mathrm{H} 2$ it appears that the 'exogenisation' discourse levels are higher for opposition parties, thus supporting our initial expectations on shifting content. This is especially evident in the case of SYRIZA at party level since coming to power in 2015, by shifting from references to 'the people' $(-1.18 \%)$ to the blame-shifting of the inner political scene $(-1.27 \%)$. A similar but rather small positive shift can be observed in the cases of the leaders of PASOK (Papandreou) and ND (Meimarakis), when placed in opposition in 2015, e.g. $+1.83 \%$ against the political established scene by ND. (see Figure 1 and Appendix 3, Figure 5). Looking more closely at the 2015 debate, another interesting observation concerns the lowest rates of 'exogenisation' by both governing parties, SYRIZA and ANEL, and also by the opposition (ND). In the case of ND, when looking at the original text of the debate we see an 
emphasis on the voting procedure, along with a focus on the shift on the memorandum discourse of SYRIZA before and after the election of 2015. SYRIZA underscores the 'contradictions' the party and its MPs have been falling into by using direct examples from government policy since winning the election. At the same time the rhetoric praises the 'responsibility' that ND has demonstrated throughout its time in government since 1974 (ND, 2015). In the cases of SYRIZA at party level and of ANEL's leader Kammenos, a common observation can be made. In comparison to the content of the previous memoranda debates, that of 2015 lacks focus on the debate, creating a sense of evasion. In SYRIZA's case the party's attention is drawn more to technicalities about procedure and specific amendments on the agreement presented to Parliament for approval. In the case of ANEL the emphasis is on a pro-consensual call on the rest of the parties, highlighting the 'dire' necessity of the measures and urging them to avoid any possible 'sabotage' (Kammenos/ANEL, 2015). It also appears that Kammenos's rhetoric is drawn specifically to issues relating to the military e.g. pensions, potential career developments and the exploitation of the military forces' assets. Despite not having a comparison with the previous debate experiences, what is obvious in the case of ANEL and its leader is the effort to highlight the military as a priority area for both himself and his party and a field of constant disagreement with their coalition partner, SYRIZA. Kammenos, at the same time, avoids addressing the memorandum itself, which is also at odds with the party's pre-election anti-memoranda rhetoric. This fragmentation at policy level could be interpreted as driven by the electoral interests of the party and the desire to circumvent any generalised position-taking which would be inevitably associated with blame attribution against ANEL in the future. Equally, SYRIZA's focus on technicalities arises from an effort not to be seen to succumb to national and international pressure and emphasise blame attribution in order to 'exogenise' the blame. Based on the outputs presented above, the analysis points also to a validation of our H2. Summing up the points of our main narrative, the level of populistic appeal appears to decrease when a party is in government (see Figure 1). This also points to the argument of responsibility versus responsiveness governments. Parties feel the 
pressure to deliver when in government, therefore they shift their discourse towards the need for responsibility, moving away from responsiveness to people's demands. Therefore, exogenisation cannot be disconnected from the general goal of political parties to maximise their vote share; in their effort to pursue office, they seek and promote policies relevant to their cause and interests.

Figure 1: Overview of salience of parliamentary discourse by leader and by party over time
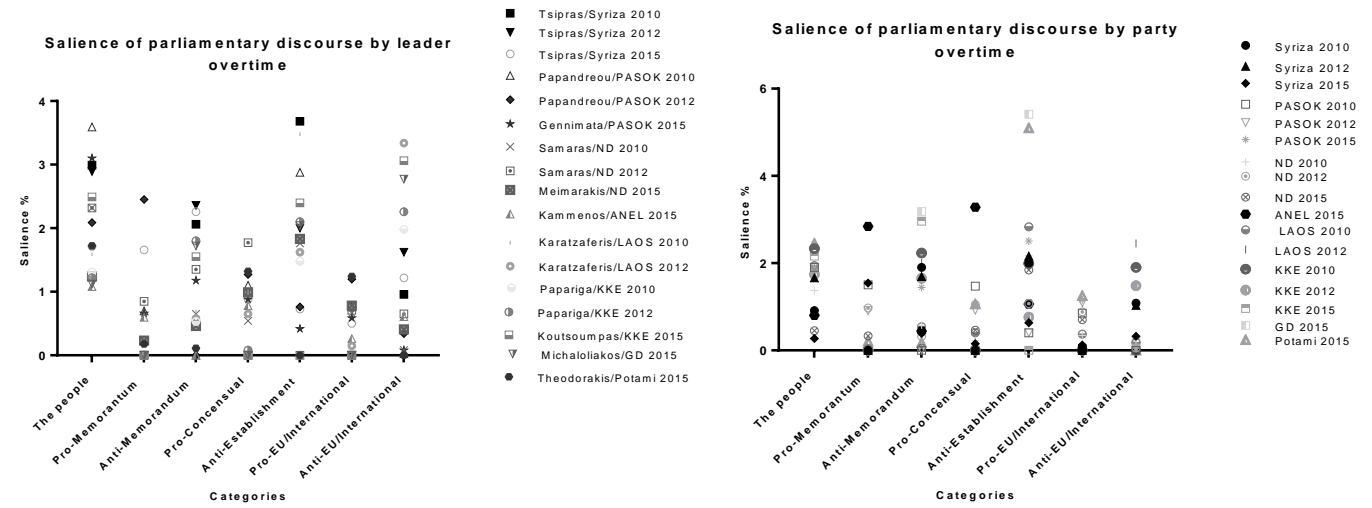

\section{Concluding remarks}

The aim of this research has been to explore blame attribution discourse and understand how it affects the dynamics of representative versus responsive government in times of crisis. We analyse the mechanisms of the 'exogenisation' of the crisis and how they develop through time (2009-2015) in Greece, how party leaders and MPs express blame attribution differently and how the discourse alters when a party enters the government. The case of Greece during the period of the three Economic Adjustment Programmes (2009-2015) offers fertile ground for moving forward the literature on blame-shifting, blame attribution and exogenisation of the crisis.

It has been shown in this article that blame shifting can be much more sophisticated than simply directing blame for the crisis and its ineffective remedies towards exogenous factors (e.g. the EU and the troika). It can involve elements of populist discourse and it can be directly linked to domestic political debate where the mainstream centrist political parties (ND, 
PASOK) are blamed by the 'protest' parties (SYRIZA, ANEL, Golden Dawn) for allying with the EU and betraying the 'people' before and during the crisis. This is what we call 'historical blame-shifting'. The key about 'historical blame-shifting' is that it allows the government in office to renounce its accountability, since the mistakes of the past are blamed for today's failures.

A second finding is that party leaders communicate blame shifting with a much stronger and often populist discourse in comparison to party members. Throughout the three parliamentary debates party leaders target the blame towards the 'old establishment' and indirectly towards the EU and the troika. They often appeal to the 'people', who are the only blameless actors. This finding is in line with the 'exogenisation' literature which claims that policy-makers have as a priority to shift the attention from the government to exogenous factors (Boin, Hart and McConnell, 2009), but moves the debate further by outlining that political parties aiming to govern do the same and that party leaders are much more polemic than MPs in their discourse. Further research is necessary in order to discover more variations that may exist in the blame attribution discourse (e.g. age or gender factors).

Finally, in the case of Greece in crisis the 'exogenisation' of the blame creates a trend, a generalised shift of blame and a change of strategy depending on whether a party is in government or in opposition. Our research indicates that there is a special weight on the importance of blame-shifting towards the EU and the main electoral rival while in opposition, a trend that instantly decreases when the party comes to power. This is in line with Mair's (2009) 'representative versus responsible government' argument and moves the debate further by showing how the controversial and often populist discourse of protest parties smoothens when in government. This is not to justify such a discourse or to say that 'exogenisation' is positive but to demonstrate that these kinds of strategies are by nature short-term since they cannot last once in government. The most telling example is that of the anti-memorandum and anti-establishment discourse of SYRIZA and ANEL: starting as protest parties that organised rallies against the bailouts in the first years of the crisis, once they had 
a formed a powerful governing coalition they supported policies that were crucial to their success. This shift has enabled the implementation of some of the reforms attached to the third Economic Adjustment Programme. Whether these reforms are well-rooted or whether they will be reversed after the end of the Programme and/or when a new government comes to power should be the focus of further research. 


\section{Bibliography}

Allcott, H. \& Gentzkow, M. (2017). 'Social Media and Fake News in the 2016 Election'.

Journal of Economic Perspectives, Vol. 31, No. 2, pp. 211-36.

Allen, N., Bara, J. and Bartle, J. (2010). 'Rules, Strategies and Words: The Content of the 2010 Prime Ministerial Debates'. Political Studies, Vol. 61, No.1, pp. 92-113

Armony, A.C., \&Armony, V. (2005). 'Indictments, myths, and citizen mobilization in Argentina: A discourse analysis'. Latin American Politics \& Society, Vol.47, No.4, pp. 27-54.

Bara, J., Weale, A., \& Bicquelet, A. 2007. 'Analysing parliamentary debates with computer assistance'. Swiss Political Science Review. Vol.13, No.4, pp. 577-605.

Bastien, F. (2018). 'Using parallel content analysis to measure mediatization of politics: The televised leaders' debates in Canada, 1968-2008'. Journalism.

https://doi.org/10.1177/1464884917751962

Boin, A., P. 't Hart and A. McConnell (2009) 'Crisis Exploitation: Political and Policy Impacts of Framing Contests'. Journal of European Public Policy, Vol. 16, No1, pp. 81-106.

Bennett, L. (2016) The Politics of Illusion. (The University of Chicago Press).

Capelos, T. and Th. Exadaktylos (2015) 'Feeling the Pulse of the Greek Dept Crisis: Affect on the Web of Blame'. National Identities, pp. 1-18.

Dinas, E. and L. Rori (2013) 'The 2012 Greek Parliamentary Elections: Fear and Loathing in the Polis'. West European Politics, Vol. 31, No1, pp. 270-282.

Ekathimerini, (7/2/17) 'Greece: IMF in Disagreement over Bailout Measures'. Available at:"http://www.ekathimerini.com/215971/article/ekathimerini/news/greece-imf-in disagreement-over-bailout-measures". Accessed 15 February 2017. 
Ekathimerini.com (15/7/2015) 'SYRIZA Committee members slam Greece agreement'.

Available at: "http://www.ekathimerini.com/199552/article/ekathimerini/news/syriza-

committee-members-slam-greece-agreement".Accessed 15 February 2017.

Eurostat (2016) Available at:

“http://ec.europa.eu/eurostat/tgm/table.do?tab=table\&init=1\&language=en\&pcode=teina2 25\&plugin=1". Accessed 15 February 2017.

Eurostat (2015) Available at: "http://ec.europa.eu/eurostat/web/lucas/data/primarydata/2015". Accessed 15 February 2017.

Finlayson, A. \& Martin, J. Br Polit (2008), “It Ain't What You Say...': British Political Studies and the Analysis of Speech and Rhetoric'. British Politics, Vol. 3, No. 4 pp. 445-464. https://doi.org/10.1057/bp.2008.21

Hatzidaki, O. and Goutsos, D. (eds.) (2017) Greece in Crisis: Combining Critical Discourse and Corpus Linguistics Perspectives. (John Benjamins Publishing Company).

Hawkins, K.A. (2009) 'Is Chaves Populist? Measuring populist discourse in comparative perspective'. Comparative Political Studies, Vol. 42, No. 8, pp. 1040-1067.

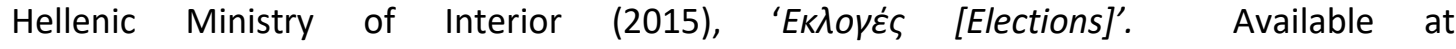
http://ekloges.ypes.gr/current/v/public/\#\{"cls":"main","params":\{\}\}; accessed 21 September 2015.

Jagers, J. and Walgrave, S. (2007) 'Populism as political communication style: An empirical study of political parties' discourse in Belgium' . European Journal of Political Research, Vol. 46, pp. 319-345.

Karyotis, G. and W. Ruedig (2015) 'Blame and Punishment? The Electoral Politics of Extreme Austerity in Greece'. Political Studies, Vol. 63, pp. 2-24. 
Konstantinidis, lannis (2015). 'Passing on the Opposite Bank: The Direct Transfers from ND to SYRIZA', Free Sunday, 07.03 [in Greek].

Krippendorff, K. (1980). Content analysis an introduction to its Methodology. London: Sage.

Ladi, S. (2016), 'Discursive Institutionalism, Problem Definition and the Consequences of Crisis for Agenda-Setting' in N. Zahariadis (ed.), Handbook of Public Policy Agenda Setting, (Edward Elgar), pp. 457-470.

Ladi S. (2014) 'Austerity Politics and Administrative Reform: The Eurozone Crisis and its Impact upon Greek Public Administration'. Comparative European Politics, Vol. 12, No. 2, pp. 184-208.

Lowen, M. (2015) 'Why Did Greece's Varoufakis bring up Nazis in Berlin?'. BBC News, 6/2/2015, Available at: "http://www.bbc.co.uk/news/world-europe-31170591".

Mair, P. (2009) 'Representative versus Responsible Government'. MPIfG Working Paper 09/8, Cologne: Max Plank Institute for the Study of Societies.

Miles, M. B., \& Huberman, A. M. (1994) Qualitative data analysis: An expanded sourcebook. (Sage Publications).

Morgan, J. (2009) 'The Limits of Central Bank Policy: Economic Crisis and the Challenge of Effective Solutions'. Cambridge Journal of Economics, Vol. 33, No. 4, pp. 581-608.

Morlino, L. and Raniolo, F. (2017) The Impact of the Economic Crisis on South European Democracies. (Palgrave Macmillan).

Mudde, C. (2007) Populist radical right parties in Europe. (Cambridge University Press).

Panizza, F. (2005) Populism and the Mirror of Democracy. Phronesis. Verso Books, London.

Papadimitriou, D. and Zartaloudis, S. (2015) 'European Discources on Managing the Greek Crisis: Denial, Distancing and the Politics of Blame'. In G. Karyotis and R. Gerodimos (eds), The 
Politics of Extreme Austerity: Greece in the Eurozone Crisis. New Perspectives on South-East Europe, Palgrave: Basingstoke, pp. 34-45.

Pappas, T. (2014) ‘Populist Democracies: Post-Authoritarian Greece and Post-Communist Hungary'. Government and Opposition, Vol. 49, No. 1, pp. 1-23.

Pappas, T. (2016) 'Modern Populism: Research Advances, Conceptual and Methodological Pitfalls, and Minimal Definition' in Politics: Oxford Research Encyclopaedias (Oxford University Press).

Pettit, P. (2012). 'The theory in practice? Spain 2004-2008'. In Marti J.L and Pettit P. (eds)A Political Philosophy in Public Life: Civic Republicanism in Zapatero's Spain. Oxford: Princeton University Press, pp. 69-108.

Powell, B. and G. Whitten (1993) 'A Cross-National Analysis of Economic Voting: Taking Account of the Political Context'. American Journal of Political Science, Vol. 37, No. 2, pp. 391414.

Rori, L. (2016) 'The 2015 Greek parliamentary elections: From great expectations to no expectations'. West European Politics, Vol 39, No. 6, pp. 1323-1343.

Rooduijn, M. and Pauwels, T. (2011). 'Measuring populism: comparing two methods of content analysis'. West European Politics, Vol. 34, No. 6, pp. 1272-1283.

Roose, J., M. Sommer, F. Scholl, M. Kousis, K. Kanellopoulos and A. Loukakis (2017) ‘Debating Responsibility on the Eurozone Crisis in Traditional Media Newspaper Reporting in Greece and Germany under a Social Media Lens'. In M. Barisione and A. Michailidou (eds.), Social Media and European Politics, Palgrave: Basingstoke, pp. 267-290.

Taggart, P. (1996) The New Populism and the New Politics: New Protest Parties in Sweden in a Comparative Perspective. (Palgrave Macmillan). 
Titscher, S., Meyer, M., Vetter, E., and Wodak, Ruth. (2000) Methods of Text and Discourse Analysis (London:Sage).

Trantidis, A. and Tsagkroni, V. (2017) 'Clientelism and corruption: Institutional adaptation of state capture strategies in view of resource scarcity in Greece'. The British journal of politics and international relations, Vol. 19, No. 2, pp. 263-281.

Vasilopoulou, S., D. Halikiopoulou and Th. Exadaktylos (2014) 'Greece in Crisis: Austerity, Populism and the Politics of Blame'. Journal of Common Market Studies, Vol. 52, No. 2, pp. 388-402.

Von Scheve, Ch., V. Zink and S. Ismer (2016) 'The Blame Game: Economic Crisis Responsibility, Discourse and Affective Framings'. Sociology, Vol. 50, No. 4, pp. 635-651.

Weaver, K. (1986) 'The Politics of Blame Avoidance'. Journal of Public Policy, Vol. 6, No. 4, pp.371-398.

Zafiropoulou, M. and Pérez, A. and Christodoulopoulou, A. and Peeva, R. and Marini, I. (2017) 'Winners and losers of the Greek Crisis as a result of a double fragmentation and exclusion: a discourse analysis of Greek civil society'. GreeSE papers, 119. Hellenic Observatory, European Institute, London, UK. Available at: "http://eprints.Ise.ac.uk/86446/1/GreeSE_119.pdf" 
Appendix 1

\section{Content analysis of parliamentary debates on exogenisation of blame}

In content analysis the text is separated into smaller units of analysis (Krippendorff, 1980) with a main goal to see if a structure content of text can support the main argument. The outputs from the analysis showed that none of the selected categories were normally distributed, as revealed by Shapiro-Wilk's test $(p<.05)$. Having said that, Spearman's rank order correlation was conducted to the established categories and determined that a moderate correlation appears in some cases e.g. positive attitudes towards the consensus and the EU/international $(r=0.499, p=0.000, n=34)$ as well as being in favour of the proposed measures $(r=0.715$, $p=0.000, n=34)$. In other words, the parties and leaders that support the memorandum in each case, also have a positive discourse towards the European and international partners and talk in favour of a consensus within the national parliament. There is additionally a negative correlation between negative attitudes towards austerity measures and positive attitudes towards the EU/International $(r=-0.589, p=0.000, n=34)$ as well as attitude against the established political scene and positive discourse towards the proposed austerity measures $(r=-0.405, p=0.000, n=34)$ and pro-consensus and anti-austerity measures $(r=-0.521, p=0.000$, $\mathrm{n}=34$ ). More specifically, as expected, on the opposite side, actors that note high salience on their anti-establishment discourse signify a low salience on their support of the proposed memorandum and equally, actors supporting a consensus within the national parliament have low salience against the austerity measures.

\section{Appendix 2}

\section{Dictionary of the computer-based content analysis (plus synonyms)}

As Miles and Huberman (1994) underline, content analysis is a procedure for identifying and classifying substantial patterns in text through the application of coding. The 'semiautomated' characterisation refers to the HAMLET II requirement of preparation of a coding system, which involves a general vocabulary of key words and terminology on the basis of 
which the analysis is conducted by searching for 'inter-connections between a number of key words that occur in a text and explore word and category associations' (HAMLET Ilsoftware manual, 2013, p. 4). Further explanation of such coding technique is derived from work by Titscher et al. (2000), where they define categories as an alternative effective definition of variables within the components of text under examination, in this case parliamentary debates. Overall, the software produces data on the basis of strategic words which are of significance to our hypotheses. The categories constructed for this research are based on general themes and reflect a broad spectrum of blame shifting that parties include in their parliamentary discourse on the specific debates under analysis.

An additional feature of HAMLET II is that it allows for the analysis of individual speakers as well as the analysis of each debate as a whole. Finally, it must be pointed out that despite the fact that only a small proportion of the words used as dictionary inputs are represented in the texts themselves, this is regarded as adequate to highlight salience in this form of research (Bara et al. 2007, Trantidis and Tsagkroni, 2017). In any form of category-based content analysis, the majority of words in a given text are present because of grammatical or linguistic convention or refer to topics not under scrutiny in the given research. In our case for instance, the total sum of the 7 categories entries for Tsipras signifies only some $9.59 \%$ in $2010,8.87 \%$ in 2012 and $9.06 \%$ in 2015.

This research defines a blame shifting index where society is being divided between the 'people' ('citizens', 'society', 'country' 'we' as the 'people') and the 'establishment', referring to the national political scene ('corrupt', 'capital', 'propaganda', 'clientele'). Additionally, the pro-consensus is highlighted by a call for consent ('agreement', 'solidarity', 'responsibility') mainly from governing parties when addressing the opposition parties in parliament, and the coding also defines positive and negative attitudes towards the international and European political factors ('IMF', 'Troika', 'EU'). Finally, as mentioned above the data are examined in terms of party leader and party representative speeches during the three memoranda parliamentary debates - a total of 43 individual texts. Collectively, the seven categories 
comprised some 107 inputs in the HAMLET II vocabulary. The texts are examined as a whole. In order to avoid coder 'bias', reliability checks were carried out to ensure that choice of pledge and coding were as accurate as possible. Additionally, in semi-automated software like HAMLET II the application of coding categories is carried out automatically so there is no reliability issue in this regard (Bara, Weale and Bicquelet 2007, p. 580).

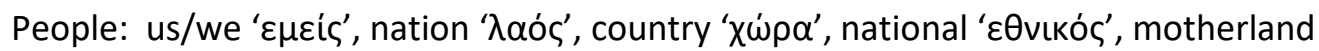

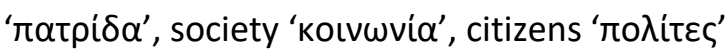

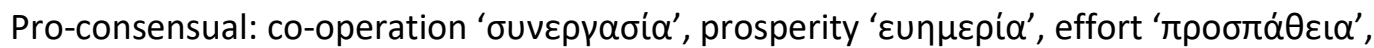
agreement ' $\sigma u \mu \phi \omega v i \alpha^{\prime}$, solidarity ' $\alpha \lambda \lambda \eta \lambda \varepsilon \varepsilon \gamma u$ u'

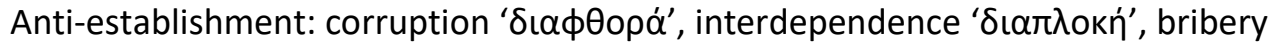

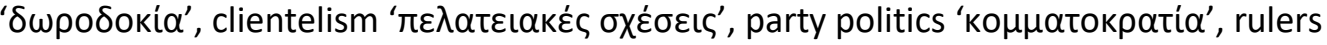

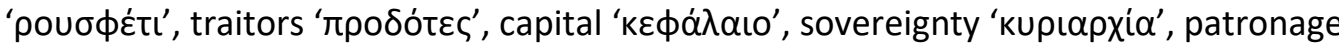

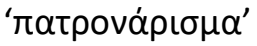

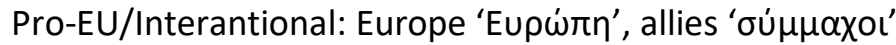

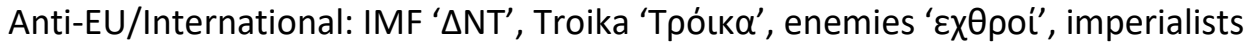

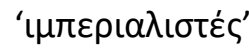

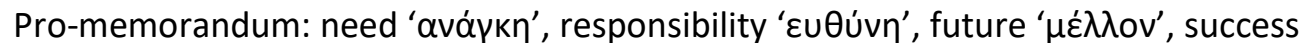
'عлıтuxía'

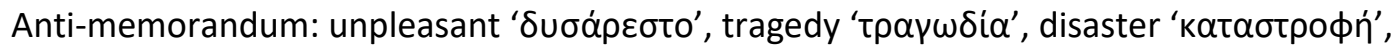

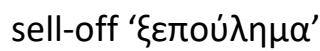


Appendix 3

Figure 2: Salience of parliamentary discourse by party and leader (2010)

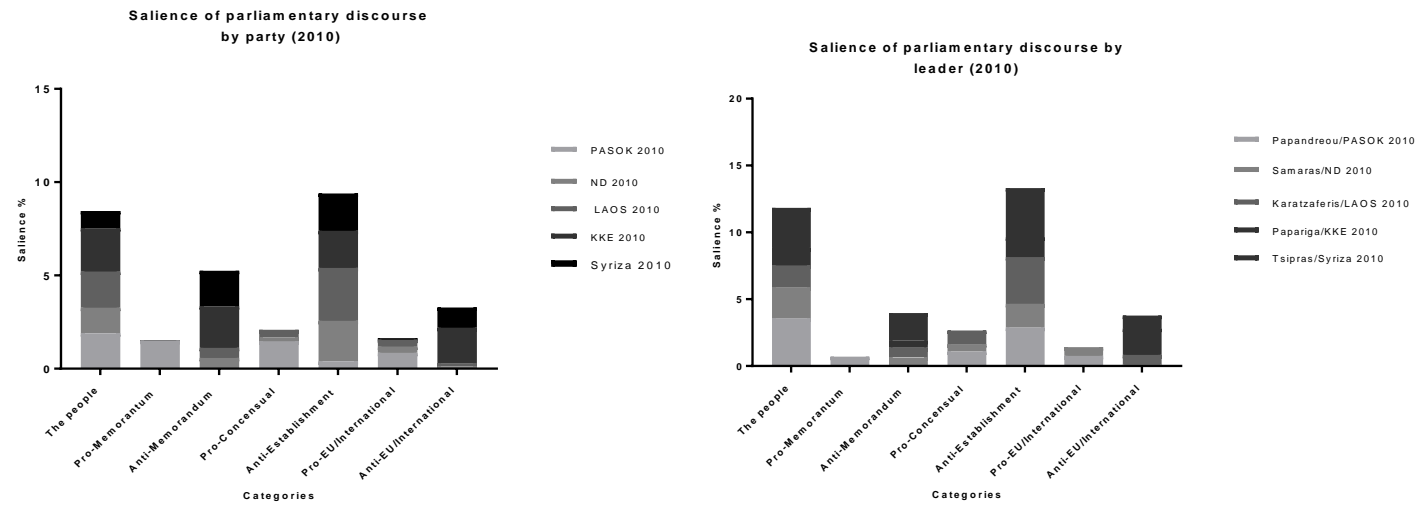

Figure 3: Salience of parliamentary discourse by party and leader 2012

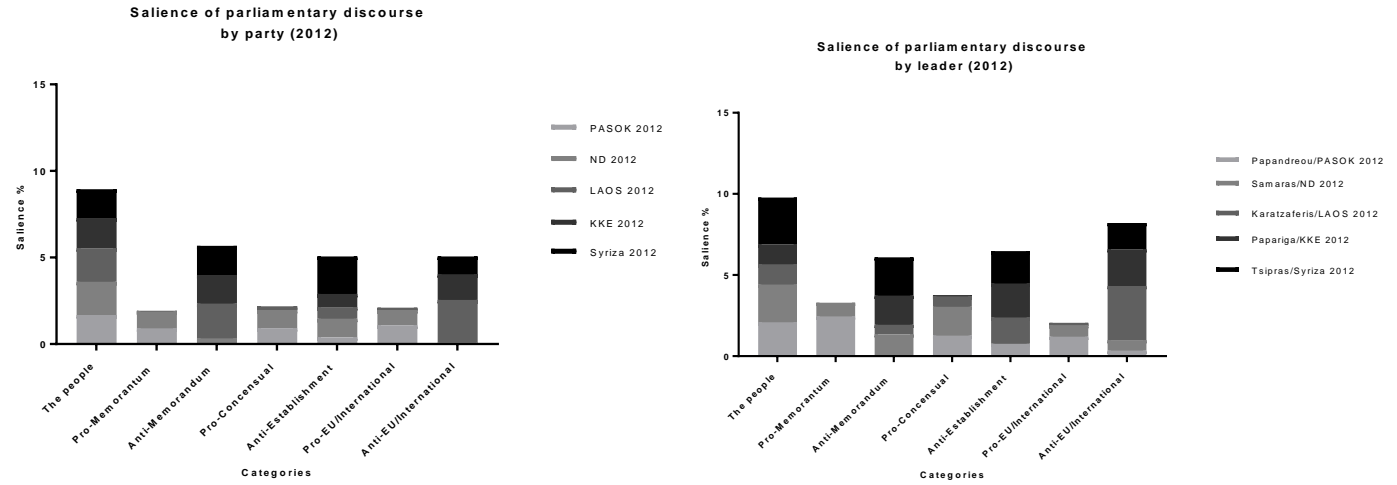

Figure 4: Salience of parliamentary discourse by party and leader 2015
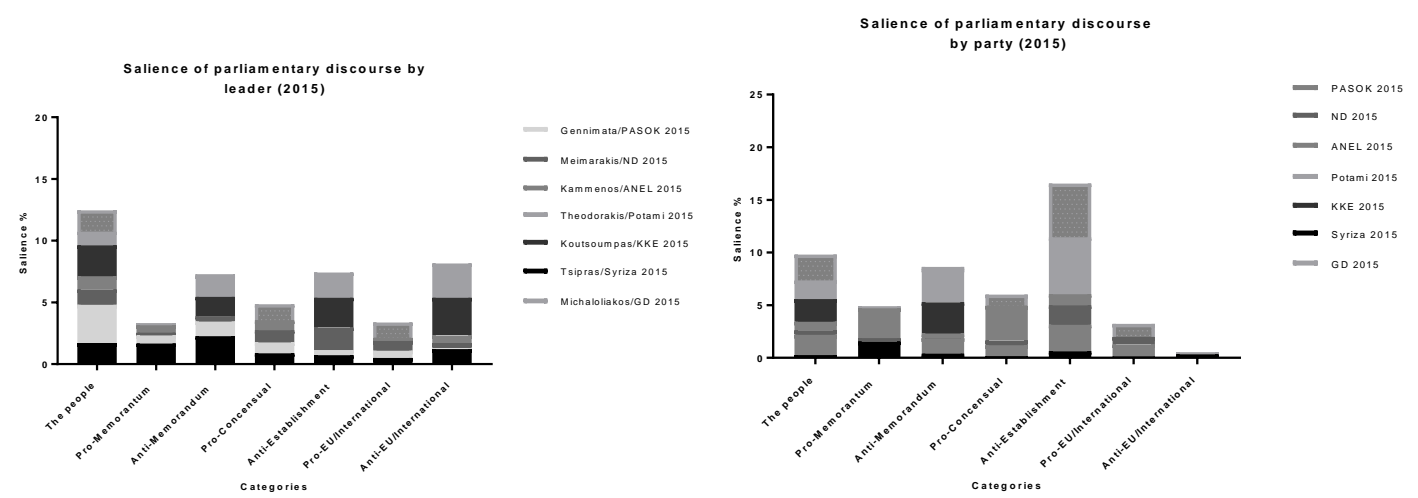
Figure 5: Salience of parliamentary discourse by year
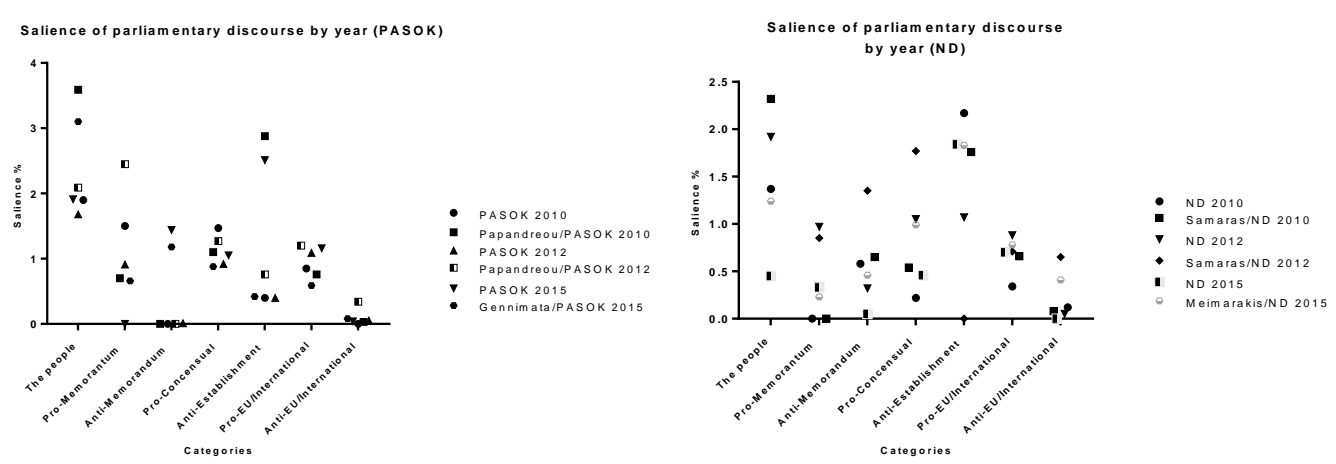

Salience of parliamentary discourse by year (SYRIZA) Salience of parliam entary discourse
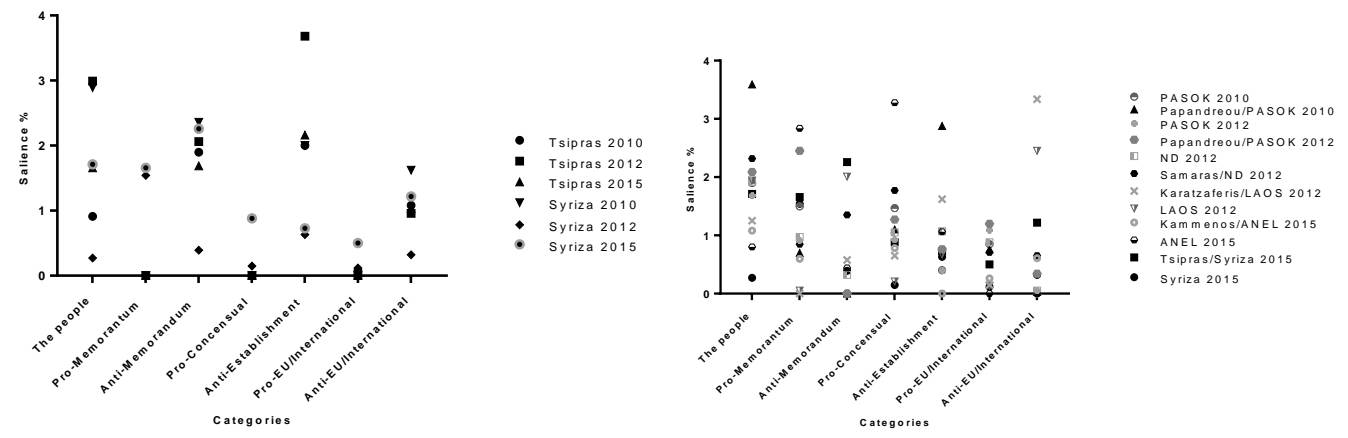